\title{
PLEUROTHALLIS CHICALENSIS, A NEW SPECIES IN SUBSECTION MACROPHYLLAE-FASCICULATAE (ORCHIDACEAE: PLEUROTHALLIDINAE) FROM NORTHWESTERN ECUADOR
}

\author{
Marco M. Jiménez ${ }^{1,2,4, *}$, Luis E. Baqueroº,3 ${ }^{2,3}$ Mark Wilson ${ }^{5}$ \& Gabriel A. Iturralde ${ }^{3}$
}

${ }^{1}$ Avenida del Ejército y Juan Izquierdo, Zamora, Zamora Chinchipe, 190102, Ecuador

2 Jardín Botánico de Quito, Pasaje \#34, Rumipampa E6-264 y Av Shyris, Interior Parque La Carolina, Quito, 170506, Ecuador

${ }^{3}$ Carrera de Ingeniería Agroindustrial y Alimentos. Facultad de Ingeniería y Ciencias Agropecuarias, Universidad de Las Américas, Calle José Queri, Quito, Pichincha, 170137, Ecuador

${ }^{4}$ Instituto Nacional de Biodiversidad, Pasaje Rumipamba 341 y Avenida de los Shyris, Quito, Pichincha, 170135, Ecuador

${ }^{5}$ Department of Organismal Biology and Ecology, Colorado College, Colorado Springs, CO 80903, USA

*Author for correspondence: mmjimenez473@gmail.com

\begin{abstract}
A new species of Pleurothallis in subsection Macrophyllae-Fasciculatae from Ecuador is described, illustrated and its relationship with other species is discussed. Pleurothallis chicalensis is compared with $P$. dewildei, from which is distinguished by the ovate leaves, the yellow flowers with broadly obovate synsepal and the transversely cordate lip with apiculate apex.

Resumen. Una especie nueva de Pleurothallis de la subsección Macrophyllae-Fasciculatae de Ecuador es descrita, ilustrada y su afinidad con otras especies es discutida. Pleurothallis chicalensis se compara con $P$. dewildei, de la cual difiere por las hojas ovadas, las flores amarillas con el sinsépalo ampliamente obovado y el labelo transversalmente cordado con el ápice apiculado.
\end{abstract}

Key words: Andes, Carchi, Pleurothallis bovilingua, Pleurothallis dewildei, taxonomy

Introduction. In the genus Pleurothallis R.Br. sensu Pridgeon et al. (2005) there are between 478 and 625 species (Wilson unpubl. data), depending on synonymy, making it the third largest genus in Pleurothallidinae, after Lepanthes Sw. and Stelis Sw. The genus is distributed from Central America and the Caribbean Islands to South America, where most of the species are epiphytes in cloud forests of the Andes (Doucette et al. 2016).

Section Macrophyllae-Fasciculatae Lindl. was created as part of Pleurothallis infrageneric classification by Lindley (1859), which was later considered by Luer (1986) in his initial systematics of genus Pleurothallis and subsequently demoted to a subsection of the same name (Luer 1988). However, in 2005 he resurrected the genus Acronia C.Presl, grouping the subsections Acroniae (C.Presl) Luer and Macrophyllae-Fasciculatae (Lindl.) Luer (Luer 2005).

Recently, phylogenetic relationships of Pleurothallis have been evaluated from DNA sequence analysis (Pridgeon et al. 2001, Wilson et al. 2011, 2013, unpubl. data). The studies revealed the close relationship of subsection MacrophyllaeFasciculatae with the type species Pleurothallis ruscifolia (Jacq.) R.Br. that supports the inclusion of this group within Pleurothallis versus Acronia (Wilson et al. 2016).

Luer (2005) in revision of subsection Macrophyllae-Fasciculatae indicated that members of the group are distinguished by their sessile leaves with a cordate base, single flowers with lateral sepals connate into a synsepal, and a bilobed stigma. Since 
Luer's revision, about a dozen new species have been described in this group, bringing the number to between 236 and 305 species, depending on synonymy (Wilson unpubl. data).

Northwestern Ecuador has been the source of several new orchid discoveries in the recent years. Exhaustive exploration carried out in the forests of El Carchi Province, near the Colombian border has resulted in the discovery of species like Porroglossum raoi Baquero \& Iturralde and Platystele baqueroi Jost \& Iturralde. In 2016, Luis Baquero found an unknown species of Pleurothallis from subsection Macrophyllae-Fasciculatae in this area. This species with intense, yellow flowers and cordate lip is described here.

\section{TAXONOMY TREATMENT}

Pleurothallis chicalensis M. Jiménez \& Baquero, sp. nov. (Fig. 1, 2A-B).

TYPE: Ecuador: El Carchi Province, near Cerro Colorado, Chical-El Carmen road, $00^{\circ} 54.74$ 'N, 78¹2.34'W, 1590 m, 4 June 2016, LB 3033 (holotype, QCNE!).

Diagnosis: Similar to Pleurothallis dewildei Luer \& R. Escobar, from which it differs in the ovate leaves, the yellow flowers with broadly obovate synsepal and the widely cordate, apiculate lip with involute margins versus the narrowly ovate leaves, purple flowers with ovate synsepal and the broadly cordateovate lip with obtuse, saccate apex of $P$. dewildei.

Plant medium in size, $c a .20 \mathrm{~cm}$ tall, epiphytic, caespitose. Roots numerous, slender ca. $1 \mathrm{~mm}$ wide. Ramicauls green, erect, slender, $10-30 \mathrm{~cm}$ long, enclosed by a tubular, brown sheath running through the second third from the base, and 1-2 other tubular sheaths near the base. Leaf green above, microscopically papillate, dull, light green underneath, perpendicular to the ramicaul, coriaceous, ovate, acuminate, $7-18 \times 4-8 \mathrm{~cm}$, edge entire, the base sessile, deeply cordate, with lobes connate for $1 \mathrm{~cm}$. Inflorescence a solitary flower, resupinate, produced successively from a reclining spathaceous bract ca. $1 \mathrm{~cm}$ long; peduncle ca. 3-5 $\mathrm{mm}$ long concealed within the spathe, floral bract $3 \times 2 \mathrm{~mm}$, pedicel ca. $6 \mathrm{~mm}$ long. Ovary $5 \mathrm{~mm}$ long, clavate, almost straight. Flower $20-23 \times 13-18 \mathrm{~mm}$, brightyellow. Sepals glabrous to microscopically papillose; dorsal sepal ovate, 12-13 $\times 8 \mathrm{~mm}$, 9-veined, obtuse, margin microscopically glandulous; synsepal broadly obovate, $10-11 \times 8-9 \mathrm{~mm}, 10$-veined, subacute, margin microscopically papillous. Petals obliquely triangular-ovate, acute, $7-8 \times 2.0-2.5 \mathrm{~mm}, 3$-veined. Lip broadly cordiform, obtuse with a minute rounded apiculus, $4 \times 4-5 \mathrm{~mm}$, 5-veined, with involute margins starting near the middle towards the apex, microscopically pubescent; the base subtruncate with a short, deflexed claw, hinged to the column-foot; glenion a small depression between the basal lobes of the lip, surrounded by a slightly convex disc, thickened to the sides. Column stout, yellow-green, $2.0 \times 1.6 \mathrm{~mm}$, stigma bilobed. Anther cap apical, yellow, narrowly deltoid. Pollinia 2 , narrowly ovoid.

Paratype: Cerro Oscuro, near Chical, $00^{\circ} 54.445^{\prime} \mathrm{N}$, $78^{\circ} 11.63$ 'W, 1499 m, 29 October 2016, Baquero 3065 (paratype: QCNE!, flowers preserved in alcohol).

Eponymy: Named after Chical, a small town in El Carchi Province of Ecuador close to the type locality.

Distribution and habitat: Pleurothallis chicalensis has been found in two localities, close to Cerro Colorado on the Chical-El Carmen road and in Cerro Oscuro near the small town of Chical (Fig. 3). Two individuals were found growing at the type locality and a population of fifteen plants was found at the second locality. It was also found around $\mathrm{La}$ Planada Natural Reserve, Department of Nariño in southwestern Colombia (Fig. 3), based on a color photograph in the book Orquideas en la Niebla (Orejuela 2011). The color and morphology of flowers is consistent between populations.

Pleurothallis chicalensis is sympatric with P. imperialis Luer and P. crucifera Luer \& Hirtz, two species confined to northwestern Ecuador. In Cerro Oscuro it is also found with Scaphosepalum swertiifolium (Rchb.f.) Rolfe, S. cimex Luer \& Hirtz and other pleurothallids. Near Cerro Colorado, it is found growing next to P. imperialis, P. crucifera, Sobralia lancea Garay, S. crocea (Poepp. \& End1.) Garay, S. macrophylla Rchb.f. and S. ecuadorana Dodson. 


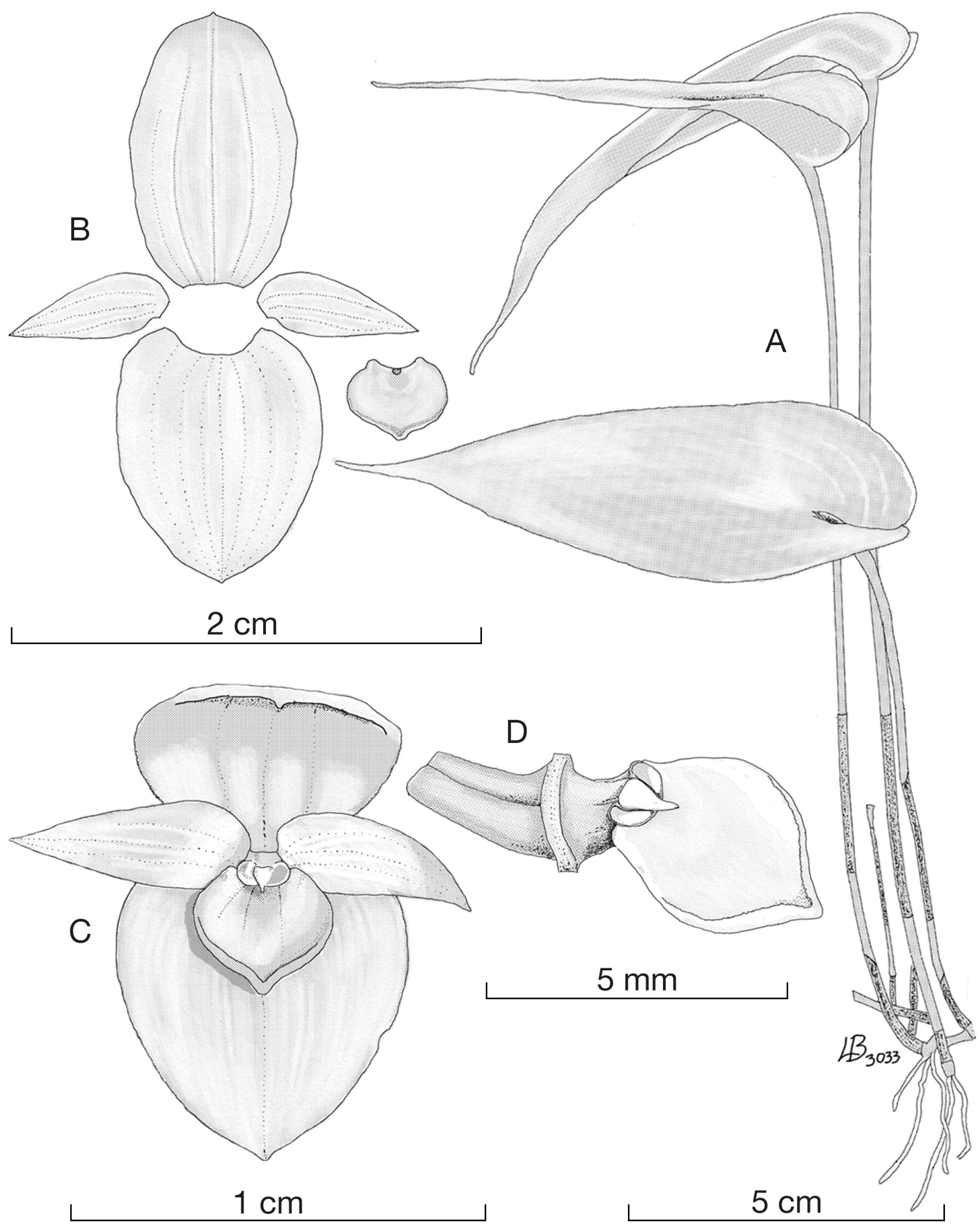

Figure 1. Pleurothallis chicalensis Jiménez \& Baquero A. Habit. B. Dissected flower. C. Flower close-up. D. Column and lip, lateral view. Illustration by Luis Baquero based on the holotype.

Conservation status: Both Ecuadorian localities are near the Colombian border, however, the plants at the type locality are threatened by road works, while the population of Cerro Oscuro is protected in Ecominga's 

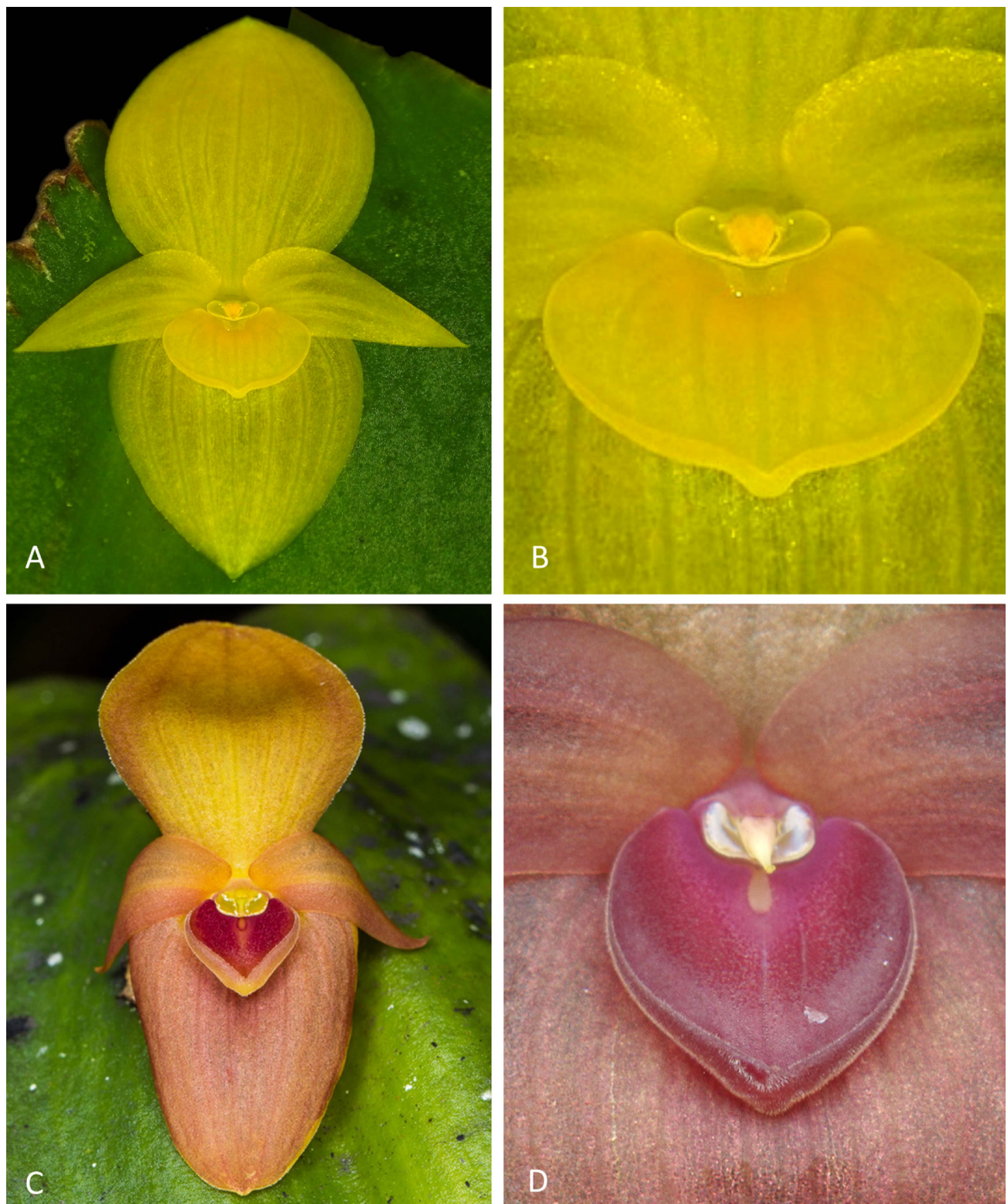

Figure 2. Pleurothallis chicalensis flower (A) and lip (B), and Pleurothallis dewildei flower (C) and lip (D). Photos by Andreas Kay (A-B), Sebastian Vieira-Uribe (C) and Mark Wilson (D).

Dracula Reserve. The status of the population near La Planada in Nariño, Colombia is unknown. Until further assessment can be performed, the species should be considered "data deficient" (DD) under IUCN criteria.
Discussion. Due to morphology and geographic proximity, $P$. chicalensis is probably most closely related to P. dewildei (Fig. 2C-D, 4-5), P. bovilingua Luer \& R. Escobar (Fig. 4-5), and P. calolalax Luer \& 


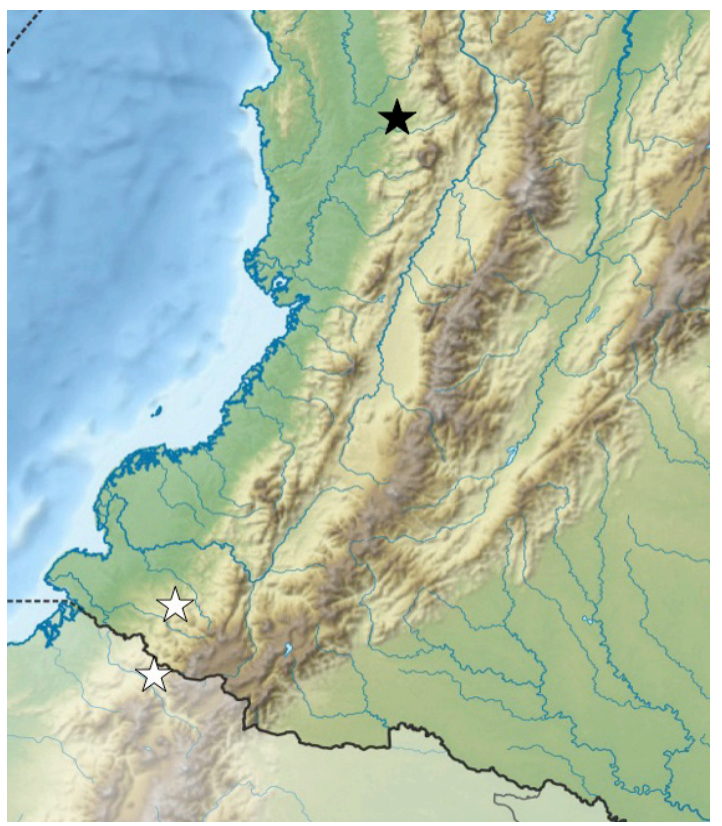

Figure 3. Distribution of Pleurothallis chicalensis (white stars) in Ecuador and Colombia and $P$. dewildei (black star) in Colombia.

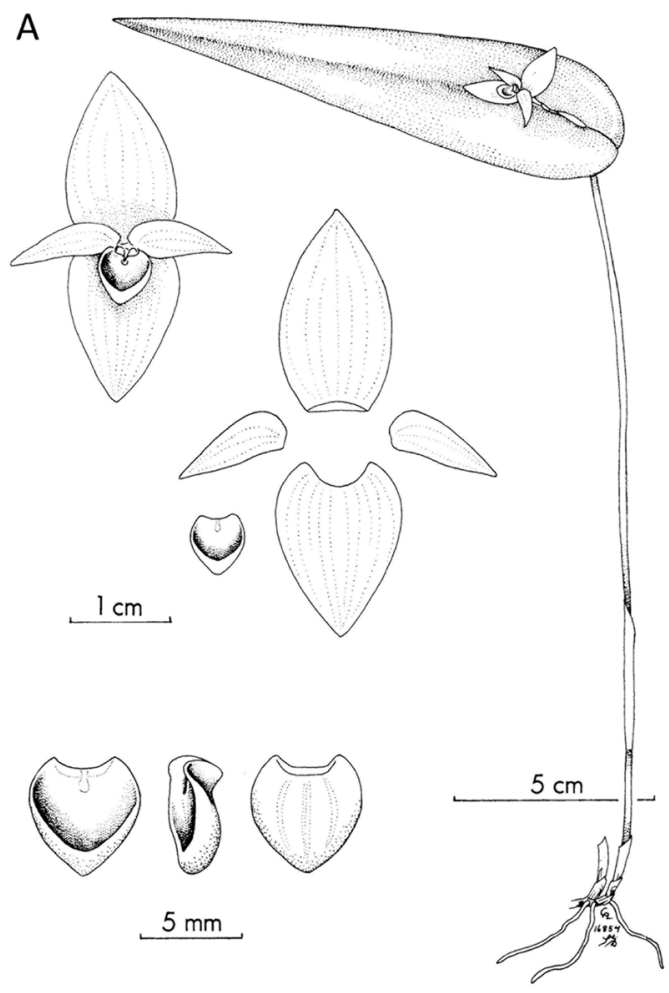

R. Escobar (Fig. 5). The vegetative and floral features shared are the unusually wide, obliquely triangular petals and the wide lip, which is remarkable in species of Macrophyllae-Fasciculatae subsection. However, $P$. chicalensis is easily recognized in this group of species inside the subsection, by the uniformly bright yellow flowers and the broadly cordate shape of the lip. Other significant differences between these species are detailed in the Table 1.

Both $P$. chicalensis and $P$. dewildei occur in the Pacific slopes of the Andes (Fig. 3). The type locality for $P$. dewildei is south of Pueblo Rico, Risaralda, Colombia, on the Pacific slope of the Western Cordillera (Luer 1998) (Fig. 3). Unfortunately, P. bovilingua was described without collection data.

ACKNOWLEDGMENTS. We acknowledge to Universidad de Las Américas (UDLA) for funding research on orchids of Ecuador. The Ministerio del Ambiente is acknowledged for issuing Environmental Research Permit 008-2016-IC-FLO-DNB/MA. We also want to thank Andreas Kay and Sebastian Vieira for giving us permission to use their photos.

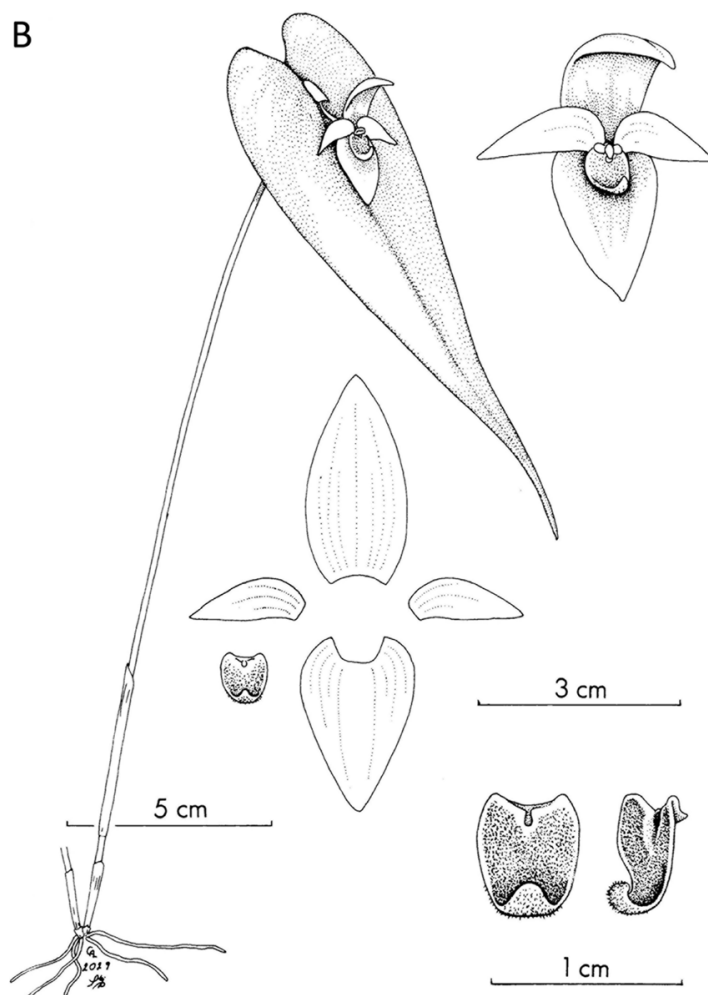

FIgure 4. Drawings of A. Pleurothallis dewildei and B. Pleurothallis bovilingua (Reproduced from Luer (2005) courtesy of Missouri Botanical Garden Press). 
A

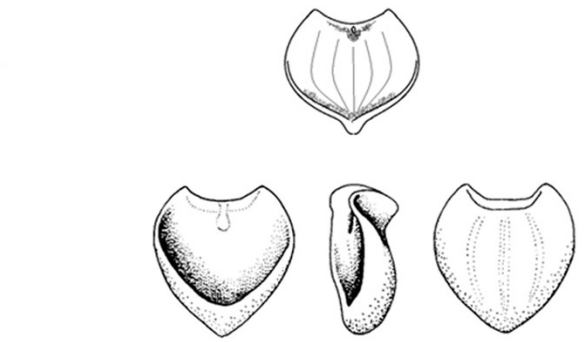

.00

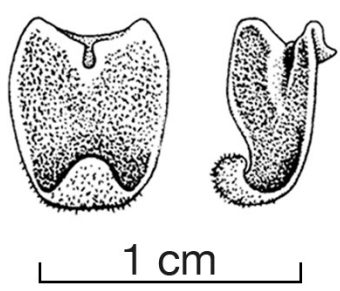

Figure 5. Lip drawings. A. Pleurothallis chicalensis, frontal view. B. Pleurothallis dewildei, frontal, lateral and ventral view. C. Pleurothallis calolalax, frontal, lateral and ventral view. D. Pleurothallis bovilingua, frontal and lateral view. (Modified from Luer (2005) courtesy of Missouri Botanical Garden).

\section{LITERATURE CITED}

Doucette, A., Wilson, M., Portilla, J., Kay, A., Moreno, J. S. \& Cameron, K. M. (2016). Dos especies nuevas de Pleurothallis y un nuevo nombre para Acronia rinkei. Orquideología, 33(2), 123-139.

Luer, C. A. (1986). Icones Pleurothallidinarum III: Systematics of Pleurothallis. Monographs in Systematic Botany from Missouri Botanical Garden, 20, 1-57.

Luer, C. A. (1988). A revision of some sections of subgenus Pleurothallis. Lindleyana, 3(3), 133-149.

Luer, C. A. (2005). Icones Pleurothallidinarum XXVII: Dryadella and Acronia section MacrophyllaeFasciculatae. Monographs in Systematic Botany from Missouri Botanical Garden, 103, 1-311.

Luer, C. A. \& Escobar, R. (1998). Nuevas especies de Pleurothallis de Colombia. Orquideología, 21(1), 72108.

Orejuela Gärtner, J. E. (2011). Orquídeas en la niebla. Cali, Colombia: Universidad Autónoma de Occidente.

Pridgeon, A. M., Solano, R. \& Chase, M. W. (2001). Phylogenetic relationships in Pleurothallidinae (Orchidaceae): Combined evidence from nuclear and plastid DNA sequences. American Journal of Botany, 88(12), 2286-2308.

Pridgeon, A. M., Cribb, P. J., Chase, M. W. \& Rasmussen F. N. (2005). (Eds.). Genera Orchidacearum. V. 4: Epidendroideae (Part 1). Oxford: Oxford University Press.

Wilson, M., Belle, C., Dang, A., Hannan, P., Kenyon, C., Low, H., Stayton, T. \& Woolley, M. (2011). A phylogenetic analysis of the genus Pleurothallis, with emphasis on Pleurothallis subsection MacrophyllaeFasciculatae, using nuclear ITS and chloroplast DNA

TABle 1. Comparison of Pleurothallis chicalensis to P. dewildei and P. bovilingua.

\begin{tabular}{|c|c|c|c|}
\hline Plant part & P. chicalensis & P. dewildei ${ }^{\mathrm{a}}$ & P. bovilingua ${ }^{a}$ \\
\hline Leaves & Ovate, $7-18 \times 4-8 \mathrm{~cm}$ & $\begin{array}{l}\text { Narrowly ovate, } 10-15 \times 3.0-4.5 \\
\mathrm{~cm}\end{array}$ & $\begin{array}{l}\text { Narrowly cordate-ovate, } 9-20 \times \\
2.5-5.0 \mathrm{~cm}\end{array}$ \\
\hline Flowers & Bright yellow & $\begin{array}{l}\text { Purple, dorsal sepal purple to } \\
\text { yellow }\end{array}$ & Light rose-brown, lip darker \\
\hline Synsepal & $\begin{array}{l}\text { Broadly ovate, obtuse, } 10-11 \\
\mathrm{~mm} \times 8-9 \mathrm{~mm}\end{array}$ & $\begin{array}{l}\text { Ovate, subacute synsepal, } 17 \times \\
12 \mathrm{~mm}\end{array}$ & $\begin{array}{l}\text { Ovate, acute, } 24-25 \mathrm{~mm} \times 17.0 \\
\mathrm{~mm} \text {, 8-veined }\end{array}$ \\
\hline Lip & $\begin{array}{l}\text { Broadly cordiform, } 4 \times 4-5 \\
\text { mm, } 5 \text {-veined, with involute } \\
\text { margins, apiculate }\end{array}$ & $\begin{array}{l}\text { Broadly cordate-ovate, } 6.0 \times 5.5 \\
\mathrm{~mm} \text {, apparently } 3 \text {-veined, concave } \\
\text { with involute margins above the } \\
\text { middle, obtuse }\end{array}$ & $\begin{array}{l}\text { Ovate, } 7 \times 6 \mathrm{~mm} \text {, apparently not } \\
\text { veined, acute, incurved }\end{array}$ \\
\hline
\end{tabular}

a Obtained from Luer (1998). 
sequencing. Lankesteriana, 11(3), 369.

Wilson, M., Belle, C., Dang A., Hannan, P., Kellogg, L., Kenyon, C., Low, H., Mochizuki, A., Nguyen, A., Sheade, N., Shan, L., Shum, A., Stayton, T., Volz, C., Vosburgh, B., Wellman, H. \& Woolley, M. (2013). A preliminary phylogenetic analysis of Pleurothallis sensu lato based upon nuclear and plastid sequences. Lankesteriana, 13(1-2), 139.
Wilson, M., Baquero, L., Dupree, K., Jiménez, M. M., LeBlanc, C. M., Merino, G., Portilla, J., Salas Guerrero, M., Tobar Suárez, F., \& Werner, J. D. (2016). Three new species of Pleurothallis (Orchidaceae: Pleurothallidinae) in subsection Macrophyllae-Fasciculatae from northern South America. Lankesteriana, 16(3), 349-350. https:// dx.doi.org/10.15517/lank.v16i3.27314 
LANKESTERIANA 